\title{
Front Matter: Volume 6849
}

, "Front Matter: Volume 6849," Proc. SPIE 6849, Design and Quality for Biomedical Technologies, 684901 (7 March 2008); doi: 10.1117/12.792115 SPIE. Event: SPIE BiOS, 2008, San Jose, California, United States 
PROGRESS IN BIOMEDICAL OPTICS AND IMAGING

Vol. 9, No. 8

\section{Design and Quality for Biomedical Technologies}

Ramesh Raghavachari

Rongguang Liang

Editors

21 January 2008

San Jose, California, USA

Sponsored and Published by

SPIE

Volume 6849

Proceedings of SPIE, 1605-7422, v. 6849

SPIE is an international society advancing an interdisciplinary approach to the science and application of light. 
The papers included in this volume were part of the technical conference cited on the cover and title page. Papers were selected and subject to review by the editors and conference program committee. Some conference presentations may not be available for publication. The papers published in these proceedings reflect the work and thoughts of the authors and are published herein as submitted. The publisher is not responsible for the validity of the information or for any outcomes resulting from reliance thereon.

Please use the following format to cite material from this book:

Author(s), "Title of Paper," in Design and Quality for Biomedical Technologies, edited by

Ramesh Raghavachari, Rongguang Liang, Proceedings of SPIE Vol. 6849 (SPIE, Bellingham, WA, 2008) Article CID Number.

ISSN 1605-7422

ISBN 9780819470249

Published by

SPIE

P.O. Box 10, Bellingham, Washington 98227-0010 USA

Telephone +1 3606763290 (Pacific Time) · Fax +1 3606471445

SPIE.org

Copyright @ 2008, Society of Photo-Optical Instrumentation Engineers.

Copying of material in this book for internal or personal use, or for the internal or personal use of specific clients, beyond the fair use provisions granted by the U.S. Copyright Law is authorized by SPIE subject to payment of copying fees. The Transactional Reporting Service base fee for this volume is $\$ 18.00$ per article (or portion thereof), which should be paid directly to the Copyright Clearance Center (CCC), 222 Rosewood Drive, Danvers, MA 01923. Payment may also be made electronically through CCC Online at copyright.com. Other copying for republication, resale, advertising or promotion, or any form of systematic or multiple reproduction of any material in this book is prohibited except with permission in writing from the publisher. The CCC fee code is 1605$7422 / 08 / \$ 18.00$.

Printed in the United States of America.

Publication of record for individual papers is online in the SPIE Digital Library.

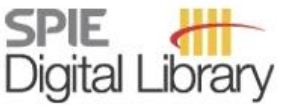

SPIEDigitallibrary.org

Paper Numbering: Proceedings of SPIE follow an e-First publication model, with papers published first online and then in print and on CD-ROM. Papers are published as they are submitted and meet publication criteria. A unique, consistent, permanent citation identifier (CID) number is assigned to each article at the time of the first publication. Utilization of CIDs allows articles to be fully citable as soon they are published online, and connects the same identifier to all online, print, and electronic versions of the publication. SPIE uses a six-digit CID article numbering system in which:

- The first four digits correspond to the SPIE volume number.

- The last two digits indicate publication order within the volume using a Base 36 numbering system employing both numerals and letters. These two-number sets start with 00, 01, 02, 03, 04 , 05, 06, 07, 08, 09, 0A, OB ... 0Z, followed by 10-1Z, 20-2Z, etc.

The CID number appears on each page of the manuscript. The complete citation is used on the first page, and an abbreviated version on subsequent pages. Numbers in the index correspond to the last two digits of the six-digit CID number. 


\section{Contents}

$\checkmark \quad$ Conference Committee

\section{SESSION 1 DESIGN OF BIOMEDICAL IMAGING TECHNOLOGIES}

684902 Recent development in multifunctional endoscope (Invited Paper) [6849-01]

K. Gono, Olympus Medical Systems Corp. (Japan)

684903 Optical coherence microscope for invariant high resolution in vivo skin imaging [6849-02] S. Murali, K. S. Lee, P. Meemon, J. P. Rolland, College of Optics \& Photonics/Univ. of Central Florida (USA)

684904 High performance time-resolved diffuse optical tomography system [6849-04]

W. Mo, N. Chen, National Univ. of Singapore (Singapore)

684905 Development and optimization of two-dimensional centering algorithm for bacterial rapid detection system using forward scattering [6849-05]

E. Bae, A. Lesmana, A. K. Bhunia, J. P. Robinson, E. D. Hirleman, Purdue Univ. (USA)

\section{SESSION 2 OPTICAL DESIGN FOR BIOMEDICAL IMAGING}

684907 An optical imaging system for window chambers in MRI system [6849-07]

Y. Lin, M. F. S. Salek, College of Optical Sciences, Univ. of Arizona (USA); N. Jennings, Univ. of Arizona (USA); A. F. Gmitro, College of Optical Sciences, Univ. of Arizona (USA) and Univ. of Arizona (USA)

684908 Optical design of a multimodal imaging system [6849-08]

R. Liang, V. Wong, P. McLaughlin, Carestream Health, Inc. (USA)

684909 Adaptive optics in ophthalmology: human eye wavefront generator [6849-09]

S. O. Galetskiy, T. Yu. Cherezova, Moscow Lomonosov State Univ. (Russia);

A. V. Kudryashov, Moscow State Open Univ. (Russia)

6849 OA Multi-wavelength source for the lower exposure intensity of spectral OCT [6849-10]

E. J. Jung, J.-S. Park, M. Y. Jeong, C.-S. Kim, Pusan National Univ. (South Korea); T. J. Eom, V. A. Tougbaev, B.-A. Yu, W. Shin, D.-K. Ko, Gwangju Institute of Science and Technology (South Korea); J.-H. Lee, Univ. of Edinburgh (United Kingdom)

\section{SESSION 3 QUALITY ASSESSMENT OF SPECTROSCOPIC SYSTEMS}

6849 OC Quantitative evaluation of ViOptix's tissue oximeter in an ex-vivo animal model [6849-12] J. J. M. Mao, ViOptix, Inc. (USA); R. Xu, Ohio State Univ. (USA); B. Lash, L. Wright, ViOptix, Inc. (USA) 
$6849 \mathrm{OE}$ Evaluation of a fiber probe coupled with half ball lens for depth-resolved fluorescence measurements [6849-14]

F. Jaillon, W. Zheng, Z. Huang, National Univ. of Singapore (Singapore)

6849 OG Validation of a fiber optic-based UVA-VIS optical property measurement system [6849-16] Q. Wang, U.S. Food and Drug Administration (USA) and Univ. of Maryland, College Park (USA); A. Agrawal, U.S. Food and Drug Administration (USA); N. S. Wang, Univ. of Maryland, College Park (USA); J. Pfefer, U.S. Food and Drug Administration (USA)

$6849 \mathrm{OH}$ Thermal properties of gold nanoshells in lipid vesicles studied by single particle tracking measurements [6849-17]

M. L. Clarke, H. Kang, P. B. Yim, R. Kishore, K. Helmerson, J. Hwang, National Institute of Standards and Technology (USA)

\section{SESSION 4 QUALITY ASSESSMENT OF IMAGING SYSTEMS}

6849 ol Validation of luminescent source reconstruction using spectrally resolved bioluminescence images [6849-18]

J. M. Virostko, A. C. Powers, E. D. Jansen, Vanderbilt Univ. (USA)

6849 OK Quantitative assessment of degradation of the optical quality of rigid endoscopes in clinical practice [6849-20]

H. J. Noordmans, S. Kruit, P. Stroosnijder, H. van den Brink, R. Verdaasdonk, Univ. Medical Ctr. Utrecht (Netherlands)

$6849 \mathrm{OL}$ Detection of abnormalities in biological tissue using optical coherence tomography [6849-21]

K. Cheong, E. Clarkson, College of Optical Sciences, Univ. of Arizona (USA); J. P. Rolland, College of Optics and Photonics, Univ. of Central Florida (USA)

\section{POSTER SESSION}

$6849 \mathrm{OP}$ Simple models for color changes in a finger during a fingerprint input action [6849-25] A. Hori, N. Takeoka, I. Fujieda, Ritsumeikan Univ. (Japan)

Author Index 


\title{
Conference Committee
}

\author{
Symposium Chairs
}

James Fujimoto, Massachusetts Institute of Technology (USA)

R. Rox Anderson, Wellman Center for Photomedicine, Massachusetts General Hospital (USA) and Harvard School of Medicine (USA)

Program Track Chairs

Tuan Vo-Dinh, Duke University (USA)

Anita Mahadevan-Jansen, Vanderbilt University (USA)

Conference Chairs

Ramesh Raghavachari, U.S. Food and Drug Administration (USA)

Rongguang Liang, Carestream Health, Inc. (USA)

Conference Cochair

Joshua Pfefer, U.S. Food and Drug Administration (USA)

Program Committee

Anthony Joseph Durkin, Beckman Laser Institute and Medical Clinic (USA)

Jeeseong Hwang, National Institute of Standards and Technology (USA)

Orhan H. Suleiman, U.S. Food and Drug Administration (USA)

Jannick Rolland, College of Optics and Photonics, University of Central Florida (USA)

\section{Session Chairs}

1 Design of Biomedical Imaging Technologies

Ramesh Raghavachari, U.S. Food and Drug Administration (USA)

2 Optical Design for Biomedical Imaging

Rongguang Liang, Carestream Health, Inc. (USA)

3 Quality Assessment of Spectroscopic Systems

Anthony Joseph Durkin, Beckman Laser Institute and Medical Clinic (USA) 
$4 \quad$ Quality Assessment of Imaging Systems

Joshua Pfefer, U.S. Food and Drug Administration (USA)

Poster Session

Ramesh Raghavachari, U.S. Food and Drug Administration (USA) 